\title{
An Investigation of the Business Performance and Manager Compensation of Taiwanese Non-Family-Controlled and Family-Controlled International Businesses
}

\author{
Yao-Hung Yang ${ }^{1}$ \\ ${ }^{1}$ Department of Business Administration, Chung Yuan Christian University, Taiwan \\ Correspondence: Yao-Hung Yang, Department of Business Administration, Chung Yuan Christian University, \\ 200, Chung Pei Rd. Chung Li, 32023, Taiwan. Tel: 886-9-2055-4772. E-mail: yaohungyang@yahoo.com.tw
}

Received: October 2, 2013

Accepted: October 21, $2013 \quad$ Online Published: November 26, 2013

doi:10.5539/ijef.v5n12p12

URL: http://dx.doi.org/10.5539/ijef.v5n12p12

\begin{abstract}
This study explores the problem of the communities of interest that form when management and ownership overlap. Samples were obtained from the Taiwan Economic Journal (TEJ) data bank from 2005 to 2011. The results of non-family-controlled international businesses show that business accounting performance is improved when directors serve as managers; however, if control rights exceed ownership rights to a great extent, business accounting performance declines. The results of family-controlled international businesses show that directors who serve as managers can monitor compensation effectively; however, if control rights exceed ownership rights to a great extent, communities of interest can pursue selfish interests. In this study, we suggest that directors serve as managers to improve business performance and supervise managers' compensation. Moreover, controlling shareholders should serve as board members with a certain proportion to prevent excessive interest assimilation.
\end{abstract}

Keywords: ownership business performance, manager compensation, non-family-controlled international business, family-controlled international business

\section{Introduction}

When management rights are greater than ownership rights, controlling shareholders may infringe on minority shareholders through their powerful management rights and lower firm value (Kao, Chen, \& Li, 2006). Lee and Yeh (2004) showed that a large deviation in management rights and ownership of controlling shareholders likely leads to financial crisis. The empirical results verify that controlling shareholders with management rights have greater incentive to engage in self-serving behavior (Morck, Shleifer, \& Vishny, 1988; Claessens, Djanlov, Fan, \& Lang, 2002). Claessens, Djankov and Lang (2000) and Yeh, Lee and Woidtke (2001) found that Taiwanese companies belong to an ownership structure of family holding patterns, and the management is under the control of the controlling shareholders. In this situation, the agency problem is not between shareholders and managers, but between controlling shareholders and minority shareholders. Liao (2010) indicated that controlling shareholders own greater internal information. Because minority shareholders cannot participate in company decision-making, causing serious information asymmetry, controlling shareholders engage in the interests of external minority shareholders.

However, do controlling shareholders violate the rights of minority shareholders, resulting in lowering company value? In contrast to the mentioned studies, the Lee and $\mathrm{Su}$ (2009) study shows that family business research, development (R\&D) commitment, and performance have a positive correlation. The empirical studies by Lins (2003) have shown that when the largest shareholder is in a position of absolute control, corporate value is enhanced over other companies, but large shareholders playing the managerial role reduce agency costs. Yen (1996) indicated that family businesses in Taiwan demonstrate a bipolar coexistence and dual-system organizational phenomena; the dual-system combines the family system and the professional manager, in which the family system controls the enterprise. However, the family system creates stable enterprise development and sustainable management. Asian societies operate under the family corporate governance structure, which differs from Western countries. The family business in the United States involves external talent, whereas in Chinese family businesses, family members control the management level (Fukuyama, 1995). Taiwanese family 
businesses possess a special ownership structure and management style, linking the enterprise to its shareholders. The lack of extensive exploration in the literature on the overlap of management rights and ownership, and the failure to propose practical suggestions, thus leads to the motivation of this study.

In this study, listed companies in Taiwan are taken as a sample, using a composite hypothesis to provide more in-depth and rigorous study to compensate for the existing literature. This paper investigates the effect of external institutional investors in corporate governance, to understand the interest assimilation among directors, supervisors, and managers, and to explore the effect of deviant ownership and management on corporate value. To avoid unnecessary conflict of interest, the shareholding ratio of external institutional investors must be kept at a certain ratio. Companies should restrict directors to serve as managers. To avoid excessive interest assimilation leading to violating the rights and interests of minority shareholders, the ratio of controlling shareholders serving as board members should be limited.

\section{Literature Review}

According to Fan and Wong (2002), ownership is highly centralized in most East Asian enterprises, and the ownership of more than half of the companies is family controlled. Studies have indicated that controlling shareholders exist in most Taiwanese enterprises, and family-control is the most common type of ownership (Claessens et al., 2000; Yeh \& Lee, 2001; Lin \& Hsu, 2008). In addition, controlling shareholders usually control personnel designation rights, and family members directly or indirectly hold crucial positions and are in charge of corporate operation; therefore, the control rights and ownership rights of businesses are unified (Yeh, 2005). In this study, this is considered an overlap of control rights and ownership rights in Taiwanese firms.

In addition to maintaining a long-term corporate status and reputation, the controlling shareholders of a company understand that surplus manipulation yields only short-term benefits, and it even damages long-term corporate performance; therefore, when the shareholding of the controlling family of a company is high, the speculative psychology of manipulating surplus is reduced (Anderson \& Reeb, 2004). Yeh (2005) discovered that when the cash-flow rights (ownership rights) of the controlling shareholders of a company in Taiwan increased $10 \%$, the corporate value increased $8.8 \%$.

Family members actively involved in management activities, ownership, and management are not completely separate; thus, controlling shareholders affect company operational decisions (Claessens et al., 2000; Faccio \& Lang, 2002). Companies adopting a moderate concentration of the shareholding structure of governance mechanisms are benefited. However, the largest shareholder of companies with highly concentrated ownership patterns violates the interest of other shareholders based on self-interests (La Porta, Lopez-de-Silanes, Shleifer, \& Vishny, 2002; Claessens et al., 2002). When the board of directors, managers, and controlling shareholders form a community of interest, the board is unable to play a supervisory role (Yang, Ling, \& Yen, 2012; Yen \& Yang, 2012). This process is called interest assimilation. Therefore, the corporate governance problem in Taiwan is to improve efficient monitoring of the company by external forces, to prevent the community of interest from gaining excessive interest assimilation, and to understand how to prevent the interest infringement of controlling shareholders on minor shareholders.

\subsection{Efficient Monitoring Power of External Shareholders}

Pound (1988) focused on the correlation between corporate management performance and institutional investors, and raised three hypotheses: the efficient-monitoring hypothesis, the conflict-of-interest hypothesis, and the strategic-alignment hypothesis. According to the efficient monitoring hypothesis, institutional investors have more abundant capital than do small shareholders, they own professionalism and a magnificent scale as support, and they can monitor managers with lower cost. According to the conflict-of-interest hypothesis, agency problems highly likely exist among institutional investors. When investment target companies obstruct the profitmaking of institutional investors, investors fight the companies with their votes and vote for corporate administrators who meet their benefits, in which monitoring is limited by the function of corporate administrators in the invested companies. Hence, this paper is based on the efficient-monitoring hypothesis (Pound, 1988), which infers that external institutional investors own professionalism and motivation to monitor the investment target company.

H1-1: The shareholding ratio of external institutional investors positively affects business performance.

Family business owners typically offer huge profits to in-group members, the board, and managers, to ensure that they not leave the family business. The incentive is higher than their contribution (Yen, 1996). Masulis, Wang and Xie (2012) determined that firms with foreign independent directors (FIDs) display poorer board meeting attendance records and higher CEO compensation, and exhibit significantly poorer performance, than 
firms without FIDs. Efficiency monitoring from outside a community of interest affects manager compensation. Therefore, when the shareholding of external institutional investors increases, firm value and manager compensation increase.

H1-2: The shareholding ratio of external institutional investors positively affects the compensation of managers.

\subsection{Interest Assimilation of the Community of Interest}

Oesterle, Richta and Fisch (2013) presented significant cubic-stretched u-shaped relationships between the stake of the largest shareholder and a firm's internationalization. The study confirmed that the theoretical assumptions of agency are applicable to the influence of the ownership structure on a firm's behavior. Therefore, the ownership structure should be considered a crucial factor for a firm's performance. The empirical results of Cheng and $\mathrm{Yu}$ (2012) support the self-interest perspective of owner-managers provided in agency theory, and indicate a U-shaped relationship between managerial ownership and the level of diversification. In other words, when the level of managerial ownership exceeds the critical level of control, owner-managers can control the firm and reap greater private and family benefits.

Weng (2000) adopted the method by La Porta, Lopez-de-Silanes and Shleifer (1999) for tracing controlling shareholders and found that family members were employed as controlling shareholders and enthusiastically participated in management to enhance control. Therefore, controlling shareholders of Taiwanese listed companies operate the firms. Thus, the following hypothesis was proposed:

H2-1: The shareholding ratio of directors serving as managers positively affects business performance.

Brick, Palmon and Wald (2005) found that the board did not play a supervisory function well. When senior managers collude with each other or cronyism occurs, director compensation is significantly positively correlated with manager compensation. Based on the literature, the controlling shareholders combined with the board of directors and managers form a community of interest (Yen \& Yang, 2012), and collusion occurs among controlling shareholders, managers, directors, and supervisors. Thus, the following hypotheses are established:

H2-2: The shareholding ratio of directors serving as managers positively affects manager compensation.

\subsection{Excessive Interest Assimilation}

Calabro, Torchia, Pukall and Mussolino (2013) showed that CEO ownership negatively impacts international sales in both family and non-family businesses. In other words, when managers concurrently own control rights and ownership rights, managers might engage in self-interested behavior.

Claessens, Djankov, Fan and Lang (1999) indicated that Taiwan is a country of collective ownership structure, in which a small number of controlling shareholders control most resources, making it more difficult for outside corporate mechanisms to fully function. When management right exceeds ownership right, controlling shareholders are more likely to infringe the interest of minor shareholders and reduce future firm value (Claessens et al., 2000; Fan \& Wong, 2002; Kao et al., 2006). These findings confirm that when controlling shareholders grasp management rights, they have more incentive to engage in self-serving behavior (Morck et al., 1988; Claessens et al., 2002). Based on the literature, the following hypothesis was proposed:

H3-1: The deviation of management rights from ownership rights negatively affects business performance.

Yang et al. (2012) indicated that a community of interest is likely to cause excessive interest assimilation; directors are unable to monitor managers, leading to a violation of minority shareholder interests. The supervisory functions of the board of directors do not actually exist (Lee \& Ma, 2006). This research indicates that members of a community of interest curry favor with each other. Based on the literature, a controlling shareholder holding greater management rights affects manager compensation. Thus, the following hypothesis is established:

H3-2: The deviation of management rights from ownership rights positively affects manager compensation.

\subsection{Controlling Variables}

External factors affect efficient monitoring, interest assimilation, and interest infringement. According to relevant literature, this study adds the following control variables to investigate the effective influence of each variable.

\subsubsection{Corporate Age}

Claessens, Djankov and Lang (1999) argued that the longer a company is established, the more easily it can be controlled by families and the more capable the controlling shareholders are of causing deviations between control rights and cash flow rights. It was thus inferred that the governance of a business is more effective when 
it is first established. After a business becomes listed, the maximum interests of the controlling shareholdings are pursued because of self-interest, and the effects of corporate governance are altered. To effectively control the influence possibly caused by corporate age on management performance, corporate age was included among the control variables examined in this study.

\subsubsection{Firm Size}

Firm size advantage enables business operations, marketing, and finance to reach economies of scale, and corporate size and corporate value are positively correlated (Demsetz \& Lehn, 1985). Gibrat (1931) defined Gibrat's law, which states that a firm's growth rate and a firm's scale are unrelated. The results of studies, such as Hart and Prais (1956) and Hymer and Pashigian (1962), have supported Gibrat's Law, but other empirical results have indicated a negative correlation, such as Evans (1987a) and Dunne and Hughes (1994), or a positive correlation, such as Singh and Whittington (1975). The larger a company is, the higher is its complexity, and managers need greater professional capacity to make higher-risk decision-making, and to pay a higher salary (Khanna \& Palepu, 1997; Oxelheim \& Randoy, 2005). Hence, firm size affects manager compensation. According to the literature, the possible effect of firm size should be given control to avoid affecting the empirical results.

\subsubsection{The Ratio of Independent Directors on the Board of Directors}

For enterprises seeking to improve the ratio of external independent directors to effectively reduce the company agency problem, the professionalism and knowledge of external independent directors can objectively monitor management performance. However, Crystal (1991) indicated that the board cannot effectively determine manager compensation because external independent directors may be assigned through senior managers, resulting in the decline of supervisory capacity, thereby affecting firm value. Therefore, the possible effect of external independent directors should be given control to avoid affecting the empirical results.

\section{Research Methodology}

\subsection{Sampling Criteria and Data Sources}

Companies listed in the Taiwan Stock Exchange Corporation were sampled in this study. The sample was obtained from the archive of the TEJ, and the research period was 2005 to 2011 . The sample companies were selected based on the following criteria: (1) International business is based investment commission approved Taiwan listed companies to have direct foreign investment; these investment areas included the United States, Canada, France, Italy, the Netherlands, Mexico, Japan, Singapore, Thailand, Malaysia, and Vietnam. (2) The aforementioned international businesses are classified as family-controlled international businesses or non-family-controlled businesses (Siebels \& Knyphausen-Aufseß, 2010). In a family-controlled international business, the shareholding ratio of the controlling shareholders of the company is higher than 5\%, and more than $50 \%$ of the seats in the board of directors are occupied by family members (Berger, Ofek, \& Yermack, 1997; Lin, 2010). (3) Companies that became full-cash delivery stocks because of bankruptcy, close-downs, or restructuring during the research period were excluded. (4) Companies without complete financial data were excluded. (5) Companies that were delisted between 2005 and 2011 were excluded.

According to Table 1, the sample included 2,864 listed companies that were considered non-family-controlled international business. Table 2 shows that 196 companies belonged to the family-controlled international business category. In addition, Tables 1 and 2 list the descriptive statistics of the variables, including the means, medians, and standard deviations of the observed values. 
Table 1. Non-family-controlled international business

\begin{tabular}{lllllll}
\hline Variable & Unit & Obs & Mean & Std. Dev. & Min & Max \\
\hline $\mathrm{rt}$ & & 2864 & 0.71976 & 0.755764 & -0.62997 & 11.29822 \\
roe & $\%$ & 2864 & 0.034225 & 0.366278 & -7.35 & 1.33 \\
bmm & Thousand Dollars & 2864 & 5251.357 & 5942.712 & 145 & 71276 \\
och & $\%$ & 2864 & 8.086236 & 8.209768 & 0 & 77.61 \\
mbh & $\%$ & 2864 & 5.473341 & 6.172743 & 0 & 38.98 \\
bi & Multiple & 2864 & 3.085761 & 3.263729 & 0.22 & 37.39 \\
age & year & 2864 & 25.87675 & 11.59895 & 2 & 64 \\
ta & Dollars & 2864 & $2.55 \mathrm{E}+07$ & $1.19 \mathrm{E}+08$ & 31436 & $2.08 \mathrm{E}+09$ \\
ind & $\%$ & 2864 & 0.155234 & 0.165843 & 0 & 0.67 \\
\hline
\end{tabular}

Note: business performance (rt); business accounting performance (roe); the compensation of managers (bmm); the shareholding ratio of external institutional investors (och); Shareholding ratio of directors serving as manager (mbh); the deviation of management rights and ownership (bi); corporate age (age); firm size (ta); the ratio of independent directors in the board of directors (ind).

Table 2. Family-controlled international business

\begin{tabular}{lllllll}
\hline Variable & & Obs & Mean & Std. Dev. & Min & Max \\
\hline $\mathrm{rt}$ & & 196 & 0.692972 & 0.67051 & -0.33799 & 4.35603 \\
roe & $\%$ & 196 & 0.173265 & 1.719295 & -2.08 & 22.29 \\
bmm & Thousand Dollars & 196 & 4224.917 & 5178.779 & 111 & 50550 \\
och & $\%$ & 196 & 6.742296 & 8.169538 & 0 & 44.41 \\
$\mathrm{mbh}$ & $\%$ & 196 & 3.588929 & 4.272195 & 0 & 23.35 \\
$\mathrm{bi}$ & Multiple & 196 & 2.52352 & 1.984421 & 0.55 & 12.58 \\
age & year & 196 & 29.89286 & 11.58486 & 8 & 58 \\
ta & Dollars & 196 & $1.19 \mathrm{E}+07$ & $1.98 \mathrm{E}+07$ & 473414 & $1.43 \mathrm{E}+08$ \\
ind & $\%$ & 196 & 0.096684 & 0.144902 & 0 & 0.43 \\
\hline
\end{tabular}

Note: business performance (rt); business accounting performance (roe); the compensation of managers (bmm); the shareholding ratio of external institutional investors (och); Shareholding ratio of directors serving as manager (mbh); the deviation of management rights and ownership (bi); corporate age (age); firm size (ta); the ratio of independent directors in the board of directors (ind).

Definitions of the research variables are shown Table 3. 
Table 3. Definitions of the research variables

\begin{tabular}{|c|c|c|}
\hline Research Variable & Code & Definition \\
\hline & & $\begin{array}{l}\text { According to Chung and Pruitt's (1994) research, the approximation } \\
\text { reaches } 96.6 \% \text {. The formula is as follows: }\end{array}$ \\
\hline $\begin{array}{l}\text { Business } \\
\text { performance }\end{array}$ & rt & $\begin{array}{l}\text { Tobin's } Q=\text { (the number of the common shares circulating outside } \times \\
\text { the price of the common shares }+ \text { the number of the preferred shares } \\
\text { circulating outside } \times \text { the price of the preferred shares }- \text { current assets } \\
+ \text { current liability }+ \text { long-term liability } / \text { the book value of total } \\
\text { assets }\end{array}$ \\
\hline $\begin{array}{l}\text { Business accounting } \\
\text { performance }\end{array}$ & roe & Net income / Stockholder's equity \\
\hline $\begin{array}{l}\text { Manager } \\
\text { Compensation }\end{array}$ & bmm & $\begin{array}{l}\text { The sum of the cash compensation and bonuses of high-level } \\
\text { managers and directors / The total number of high-level managers } \\
\text { and directors. }\end{array}$ \\
\hline $\begin{array}{l}\text { Shareholding ratio } \\
\text { of external } \\
\text { institutional } \\
\text { investors }\end{array}$ & och & $\begin{array}{l}\text { External institutional investors' shareholding is not controlled by } \\
\text { ultimate controllers. }\end{array}$ \\
\hline $\begin{array}{l}\text { Shareholding ratio } \\
\text { of directors serving } \\
\text { as manager }\end{array}$ & $\mathrm{mbh}$ & $\begin{array}{l}\text { Shares held by directors concurrently serving as managers in } \\
\text { proportion to the total number of shares the company has issued. }\end{array}$ \\
\hline $\begin{array}{l}\text { Deviation of } \\
\text { management right } \\
\text { and ownership }\end{array}$ & bi & $\begin{array}{l}\text { The board seat control-voting right divergence (bi) represents the } \\
\text { deviation of management right and ownership. Bi means } \\
\text { the board seat control of the ultimate controller divided by } \\
\text { shareholding control. Board seat control means the ratio of director } \\
\text { and supervisor seats under the control of the ultimate controller. } \\
\text { Shareholding control means the ratio of shares directly and indirectly } \\
\text { held by the ultimate controller. }\end{array}$ \\
\hline Corporate age & age & 2011-the found year of an enterprise \\
\hline Fim size & ta & Size is measured by total company assets. \\
\hline $\begin{array}{l}\text { The ratio of } \\
\text { independent } \\
\text { directors in the } \\
\text { board of directors }\end{array}$ & ind & $\begin{array}{l}\text { Independent director seats are divided by the total seats of a board of } \\
\text { directors }\end{array}$ \\
\hline
\end{tabular}

Source: TEJ (2011).

\subsection{Statistical Methods and Procedures}

This research employs panel data model to handle cross-sectional heterogeneity and time-series autocorrelation. According to the intercept characteristic, two panel data models are adopted: a model based on the presumption that the intercept varies with the analytic unit, but not with the change of time, called the fixed effects model, and a model that presumes that the intercept changes with different analytic units and times, called the random effects model. The following test results determine the appropriate model to apply.

For choosing the fixed or random effects model, Mundlak (1978) argued that if the intercept of the random effect model is correlated with the explanatory variable, errors can occur and the fixed effects model should be adopted. However, if the error of the intercept is not correlated with the explanatory variable, the random effects model can be used. Hausman (1978) proposed a test method to decide whether to apply the fixed or random effects model, as follows:

$$
\text { H0: } \mathrm{E}(\mu, \mathrm{Xitk})=0 \quad \mathrm{H} 1: \mathrm{E}(\mu, \mathrm{Xitk}) \neq 0
$$

The calculation is shown below. 


$$
\omega=(\hat{b}-\hat{B})[\operatorname{Var}(\hat{b})-\operatorname{Var}(\hat{B})]^{-1}(\hat{b}-\hat{B}) \sim \chi^{2}(k)
$$

In the calculation, $\hat{b}$ is the estimate obtained through the fixed effects model, and $\hat{B}$ is obtained through the random effects model. If the test result does not reject $\mathrm{H} 0$, the random effects model should be applied. If it does, the fixed effects model should be applied.

\subsection{Correlation Coefficients}

Pearson correlation analysis was used in this study to evaluate whether variables influenced one another and had collinearity. Tables 4 and 5 show that the correlation coefficients among the variables of the electronic industrial and traditional industrial companies were all lower than .75, indicating that a significant strong correlation did not exist among the variables (Portney \& Watkins, 2000).

Table 4. Correlation coefficient analysis of non-family-controlled international business

\begin{tabular}{llllllllll}
\hline & $\mathrm{rt}$ & roe & bmm & och & mbh & bi3 & age & ta & ind \\
\hline rt & 1 & & & & & & & & \\
roe & 0.116 & 1 & & & & & & & \\
bmm & -0.010 & 0.002 & 1 & & & & & & \\
och & -0.008 & 0.004 & 0.164 & 1 & & & & & \\
mbh & 0.038 & 0.006 & -0.096 & -0.199 & 1 & & & & \\
bi & -0.014 & 0.008 & 0.249 & 0.171 & -0.197 & 1 & & & \\
age & -0.024 & 0.004 & -0.056 & -0.105 & -0.059 & -0.049 & 1 & & \\
ta & -0.035 & 0.033 & 0.002 & 0.021 & -0.036 & 0.007 & 0.013 & 1 & \\
ind & -0.043 & -0.006 & 0.027 & -0.041 & 0.156 & -0.075 & -0.394 & -0.004 & 1
\end{tabular}

Note: business performance (rt); business accounting performance (roe); the compensation of managers (bmm); the shareholding ratio of external institutional investors (och); Shareholding ratio of directors serving as manager (mbh); the deviation of management rights and ownership (bi); corporate age (age); firm size (ta); the ratio of independent directors in the board of directors (ind).

Table 5. Correlation coefficient analysis of family-controlled international business

\begin{tabular}{llllllllll}
\hline & $\mathrm{rt}$ & roe & bmm & och & mbh & bi3 & age & ta & ind \\
\hline rt & 1 & & & & & & & & \\
roe & 0.104 & 1 & & & & & & & \\
bmm & 0.350 & 0.085 & 1 & & & & & & \\
och & -0.038 & 0.066 & -0.073 & 1 & & & & & \\
mbh & -0.072 & 0.192 & 0.023 & -0.007 & 1 & & & & \\
bi & -0.060 & -0.157 & -0.072 & 0.245 & -0.054 & 1 & & & \\
age & 0.093 & 0.032 & 0.104 & -0.119 & 0.047 & 0.120 & 1 & & \\
ta & 0.262 & 0.059 & 0.650 & -0.057 & 0.028 & -0.050 & 0.175 & 1 & \\
ind & 0.038 & 0.056 & -0.012 & 0.132 & -0.123 & -0.179 & -0.410 & -0.150 & 1
\end{tabular}

Note: business performance (rt); business accounting performance (roe); the compensation of managers (bmm); the shareholding ratio of external institutional investors (och); Shareholding ratio of directors serving as manager (mbh); the deviation of management rights and ownership (bi); corporate age (age); firm size (ta); the ratio of independent directors in the board of directors (ind).

\section{Empirical Result}

The Hausman test must be applied to examine the various hypotheses on the intercept to identify the appropriate 
estimation mode. When the F-test value is greater than 0.05 , the ols model is superior to the fixed-effects model. When the chi square of the Hausman test is smaller than .05, H0 is rejected and the fixed effects model is superior to the random effects model. Table 6 shows that the F-test value of $1 \mathrm{~b}$ was 0.999 ; therefore, the ols model was applied in this study. Moreover, the chi square values were all greater than .05 . Therefore, the random effects model was applied to analyze non-family-controlled international business. For family-controlled international business analysis, Table 7 shows that the chi square value of 1 a was lower than .05 . Therefore, the fixed effects model is applied. The chi square value of $1 \mathrm{~b}$ was larger than .05 ; therefore, the random effects model was applied. Finally, the F-test result of $1 \mathrm{c}$ was greater than 0.05 ; therefore, the ols model was applied.

To prevent an endogenous problem, the study also used three-stage least squares (3SLS) estimation to analyze the hypotheses in Model 2. An additional robustness test, Stata robust command, was used to ensure that all variables were dependent, not heterogeneous. Moreover, roe, accounting performance, was used as a robustness measure.

Table 6. Empirical result of non-family-controlled international business

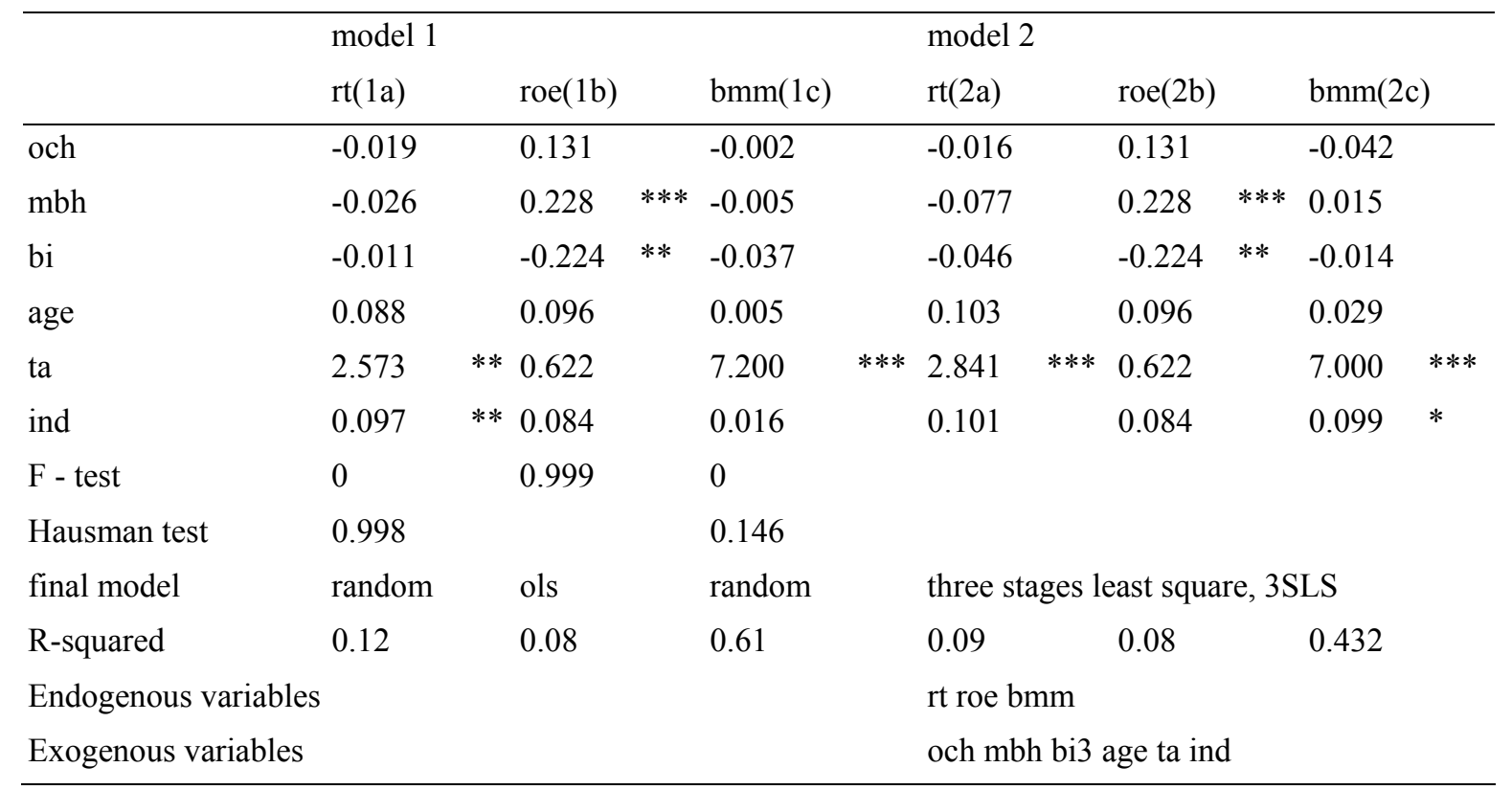

Note: business performance (rt); business accounting performance (roe); the compensation of managers (bmm); the shareholding ratio of external institutional investors (och); Shareholding ratio of directors serving as manager (mbh); the deviation of management rights and ownership (bi); corporate age (age); firm size (ta); the ratio of independent directors in the board of directors (ind).

According to Table 6 above, the shareholding ratio of external institutional investors did not significantly positively affect the business performance of the non-family-controlled international businesses in Models 1 and $2(\beta=-0.019, \mathrm{p}>.01,1 \mathrm{a}$ of Model $1 ; \beta=0.131, \mathrm{p}>.01,1 \mathrm{~b}$ of Model $1 ; \beta=-0.016, \mathrm{p}>0.01,1 \mathrm{a}$ of Model 2$),(\beta=$ $0.131, \mathrm{p}>0.01,1 \mathrm{~b}$ of Model 2 ). The shareholding ratio of external institutional investors did not significantly positively affect the compensation of managers $(\beta=-0.002, p>0.01,1 \mathrm{c}$ of Model $1 ; \beta=-0.042, p>0.01,1 \mathrm{c}$ of Model 2). The empirical results did not support Hypotheses 1-1 and 1-2 in this study.

The shareholding ratio of directors serving as managers did not significantly positively affect business performance $(\beta=-0.026, p>0.01,1 \mathrm{a}$ of Model 1). However, the shareholding ratio of directors serving as managers significantly positively affected business accounting performance $(\beta=0.228, \mathrm{p}<0.05,1 \mathrm{~b}$ of Model 1$)$. The shareholding ratio of directors serving as managers did not significantly positively affect business performance $(\beta=-0.077, p>0.01,1$ a of Model 2 ), but significantly positively affected business accounting performance $(\beta=0.228, p<0.01,1 \mathrm{~b}$ of Model 2$)$. The results partially supported Hypothesis $2-1$. The shareholding ratio of directors serving as managers did not significantly positively affect the compensation of managers $(\beta=-0.005, p>0.01,1 \mathrm{c}$ of Model $1 ; \beta=0.015, p>0.01,1 \mathrm{c}$ of Model 2). The results did not support Hypothesis 2-2 in this study.

The deviation of management rights from ownership rights did not significantly negatively affect business 
performance $(\beta=-0.011, p>0.01$, 1a of Model 1). However, the deviation of management rights from ownership rights significantly negatively affected business accounting performance $(\beta=-0.224, p<0.05,1 \mathrm{~b}$ of Model 1$)$. The deviation of management rights from ownership rights did not significantly negatively affect business performance ( $\beta=-0.046, p>0.01$, 1a of Model 2). However, the deviation of management rights from ownership rights significantly negatively affected business accounting performance $(\beta=-0.224, p<0.05,1 \mathrm{~b}$ of Model 2). The results partially supported Hypothesis 3-1. The deviation of management rights from ownership rights did not significantly positively affect the compensation of managers $(\beta=-0.037, p>0.01,1 \mathrm{c}$ of Model $1 ; \beta=-0.014, p>$ $0.01,1 \mathrm{c}$ of Model 2). The results did not support Hypothesis 3-2 in this study.

Table 7. Empirical result of family-controlled international business

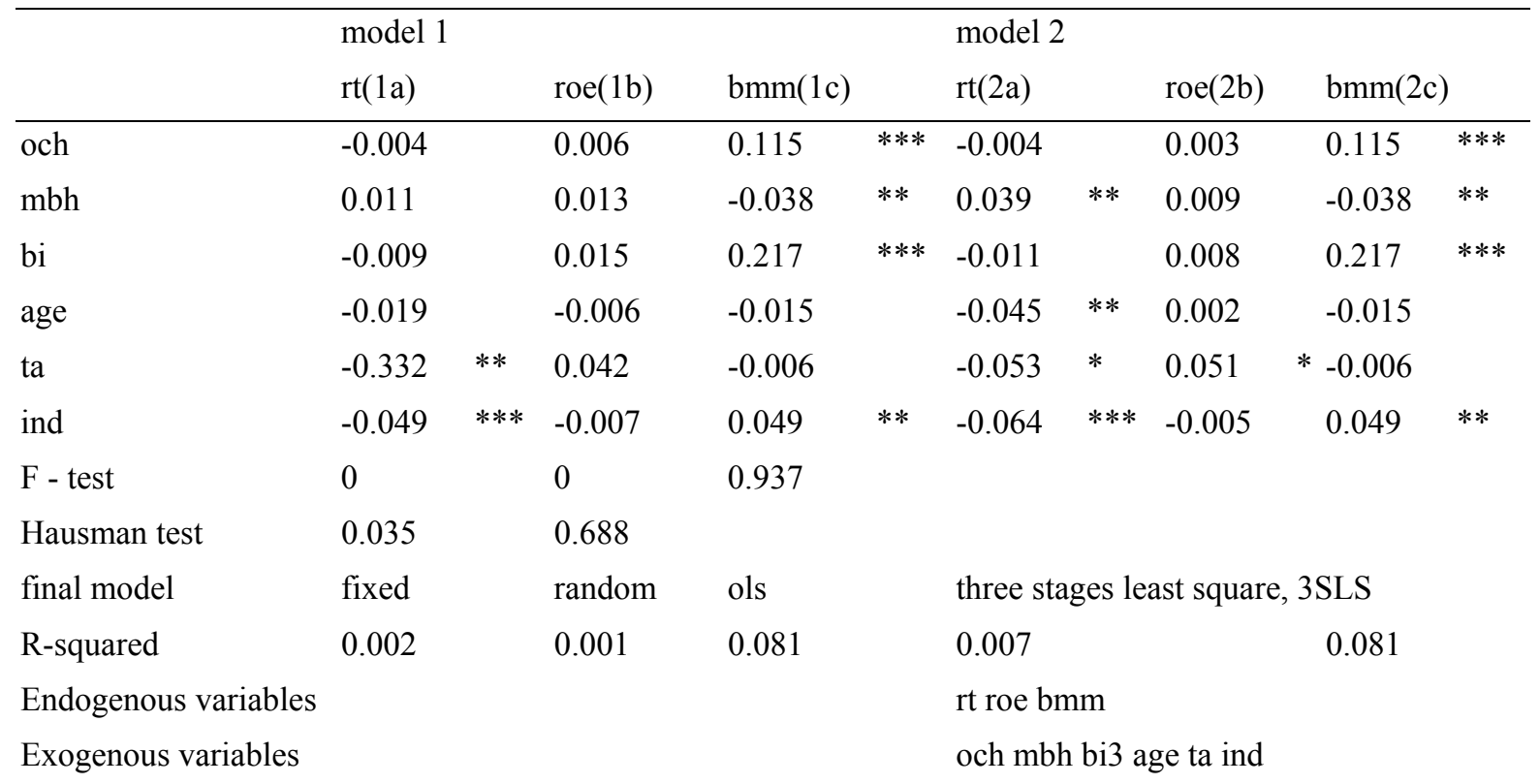

Note: business performance (rt); business accounting performance (roe); the compensation of managers (bmm); the shareholding ratio of external institutional investors (och); Shareholding ratio of directors serving as manager (mbh); the deviation of management rights and ownership (bi); corporate age (age); firm size (ta); the ratio of independent directors in the board of directors (ind).

According to Table 7 above, the shareholding ratio of external institutional investors did not significantly positively affect the business performance of the family-controlled businesses in Models 1 and $2(\beta=-0.004, p>$ 0.01 , 1a of Model 1; $\beta=0.006, p>0.01,1 \mathrm{~b}$ of Model 1; $\beta=-0.004, \mathrm{p}>0.01,1 \mathrm{a}$ of Model 2; $\beta=0.003, \mathrm{p}>0.01,1 \mathrm{~b}$ of Model 2). The results did not support Hypothesis 1-1. The shareholding ratio of external institutional investors significantly positively affected the compensation of managers $(\beta=0.115, \mathrm{p}<0.01,1 \mathrm{c}$ of Model $1 ; \beta=0.115, \mathrm{p}<$ $0.01,1 \mathrm{c}$ of Model 2). The empirical results supported Hypothesis 1-2 in this study.

The shareholding ratio of directors serving as managers did not significantly positively affect business performance and accounting performance $(\beta=0.011, p>0.01,1$ a of Model $1 ; \beta=0.013, p>0.01,1 \mathrm{~b}$ of Model 1). The shareholding ratio of directors serving as managers significantly positively affected business performance ( $\beta=0.039, p<0.05,1$ a of Model 2$)$, but did not significantly positively affect business accounting performance ( $\beta=0.009, \mathrm{p}>0.01,1 \mathrm{~b}$ of Model 2$)$. The results partially supported Hypothesis $2-1$. The shareholding ratio of directors serving as managers significantly negatively affected the compensation of managers $(\beta=-0.038, p<$ $0.05,1 \mathrm{c}$ of Model $1 ; \beta=-0.038, \mathrm{p}<0.05,1 \mathrm{c}$ of Model 2). Therefore, the results did not support Hypothesis $2-2$ in this study.

The deviation of management rights from ownership rights did not significantly negatively affect business performance and accounting performance $(\beta=-0.009, \mathrm{p}>0.01,1 \mathrm{a}$ of Model $1 ; \beta=0.015, \mathrm{p}>0.01,1 \mathrm{~b}$ of Model 1; $\beta=-0.009, p>0.01,1 \mathrm{a}$ of Model 1; $\beta=-0.011, \mathrm{p}>0.01$, $1 \mathrm{a}$ of Model $2 ; \beta=0.008, \mathrm{p}>0.01,1 \mathrm{~b}$ of Model 2). The empirical result did not support Hypothesis 3-1. The deviation of management rights from ownership rights significantly positively affected the compensation of managers $(\beta=0.217, \mathrm{p}<0.01,1 \mathrm{c}$ of Model $1 ; \beta=0.217, \mathrm{p}<$ $0.01,1 \mathrm{c}$ of Model 2). The results supported Hypothesis 3-2 in this study. 


\section{Conclusion and Suggestion}

Unlike Western countries, management and ownership in Taiwan is an overlap phenomenon, resulting in the board losing its supervisory function. Corporate external monitoring is more difficult to fully operate (Claessens et al., 1999). The empirical results of the study show that the shareholding ratio of external institutional investors did not significantly positively affect business performance in non-family-controlled international business or family-controlled international business. The results show that the external monitoring forces of non-family-controlled and family-controlled international business are not effective, verifying the conclusion by Claessens et al. (1999). However, in contrast to non-family-controlled international businesses, the shareholding ratio of external institutional investors significantly positively affected electronic, industrial, and traditional industrial company managers' compensation in family-controlled international businesses. Controlling shareholders combined with the board of directors and managers, forming a community of interest (Yang et al., 2012) that operates the firm. The results of non-family-controlled international businesses show that the shareholding ratio of directors serving as managers significantly positively affected accounting performance, indicating that the directors of non-family-controlled international businesses should be encouraged to serve as managers.

An extensive interest assimilation of the community of interest, which leads to supervision, is not effective and reduces firm value. In this situation, company managers profit personally, confirming the view of interest assimilation by Yang et al. (2012). The results verified that the deviation of management rights from ownership rights significantly negatively affected the business accounting performance of non-family-controlled international businesses. In contrast, the deviation of management rights and from ownership rights significantly positively affected the business compensation of managers. The members of a community of interest enjoy more inside information, causing severe information asymmetry, which leads to the pursuit of self-interest. These behaviors may infringe on the interests of external minority shareholders, causing severe agency problems (Chong, 2010; Liao, 2010; Yang et al., 2012).

The results of this study show that non-family-controlled international business can improve business performance by expanding the scale of the firm (Singh \& Whittington, 1975). The results of this study show that business performance declines and accounting performance improves when a family-controlled international business expands the scale of the firm (Evans, 1987; Dunne \& Hughes, 1994).

\subsection{Managerial Relevance}

The results of non-family-controlled international businesses companies indicate that, when directors serve as managers, business accounting performance is enhanced; however, when control rights considerably exceed ownership rights, business accounting performance declines. The results of family-controlled international businesses indicate that directors who serve as managers can monitor the compensation of a manager effectively; however, if control rights exceed ownership rights to a great extent, communities of interest can pursue selfish interests.

This paper indicates that directors should serve as managers to enhance business performance and oversee managers' compensation. In addition, controlling shareholders should serve as board members with a certain proportion to prevent excessive interest assimilation.

\subsection{Research Limitations}

The controlling shareholders of listed companies frequently own the stocks of their company using the names of other people, which indirectly causes the shareholding ratio to be inaccurate and possibly underestimated. If laws and decrees can be strictly enforced to eliminate this phenomenon in the future, efficiency monitoring and the convergence of interest of controlling shareholders may be seen to have a different influence on business performance or the compensation of manager.

\section{References}

Berger, P., Ofek, E., \& Yermack, D. (1997). Managerial entrenchment and capital structure decisions. Journal of Finance, 52(4), 1411-1438. http://dx.doi.org/10.1111/j.1540-6261.1997.tb01115.x

Brick, I. E., Palmon, O., \& Wald, J. K. (2005). CEO compensation, director compensation and firm performance: Evidence of cronyism. Journal of Corporate Finance, 12(3), 403-423. http://dx.doi.org/10.1016/j.jcorpfin.2005.08.005

Calabro, A., Torchia, M., Pukall, T., \& Mussolino, D. (2013). The influence of ownership structure and board strategic involvement on international sales: The moderating effect of family involvement. International 
Business Review, 22, 509-523. http://dx.doi.org/10.1016/j.ibusrev.2012.07.002

Chen, C. J., \& Yu, C. M. J. (2012). Managerial ownership, diversification, and firm performance: Evidence from an emerging market. International Business Review, 21, 518-534. http://dx.doi.org/10.1016/j.ibusrev.2011.06.002

Chong, B. S. (2010). The impact of divergence in voting and cash-flow rights on the use of bank debt. Pacific-Basin Finance Journal, 18(2), 158-174. http://dx.doi.org/10.1016/j.pacfin.2009.10.002

Chung, K. H., \& Pruitt, S. W. (1994). A simple approximation of Tobin's Q. Financial Management, 23(3), 7074. http://dx.doi.org/10.2307/3665623

Claessens, S., Djankov, S., \& Lang, L. H. P. (2000). The separation of ownership and control in East Asia corporations. Journal of Financial Economics, 58(1-2), 81-112. http://dx.doi.org/10.1016/S0304-405X(00)00067-2

Claessens, S., Djankov, S., Fan, J. P. H., \& Lang, L. H. P. (1999). Expropriation on minority shareholders: Evidence from East Asia. Police research working paper 2088, The world Bank.

Claessens, S., Djanlov, S., Fan, J. P. H., \& Lang, L. H. P. (2002). Disentangling the incentive and entrenchment effects of large shareholdings. Journal of Finance, 57(6), 2741-2771. http://dx.doi.org/10.1111/1540-6261.00511

Crystal, G. S. (1991). Do directors earn their keep? Fortune, 123(9), 52-54.

Demsetz, H., \& Lehn, K. (1985). The structure of corporate ownership: Causes and consequences. Journal of Political Economy, 93(6), 1155-1177. http://dx.doi.org/10.1086/261354

Dunne, P., \& Hughes, A. (1994). Age, size growth and survival: UK companies in the 1980s'. Journal of Industrial Economics, 42, 115-140. http://dx.doi.org/10.2307/2950485

Evans, D. S. (1987a). The relationship between firm growth, size, and age: Estimates for 100 manufacturing industries. Journal of Industrial Economics, 35(4), 567-581. http://dx.doi.org/10.2307/2098588

Faccio, M., \& Lang, L. H. P. (2002). The ultimate ownership of Western European corporations. Journal of Financial Economics, 65(3), 365-395. http://dx.doi.org/10.1016/S0304-405X(02)00146-0

Fan, J. P. H., \& Wong, T. J. (2002). Corporate ownership structure and the informativeness of accounting earnings in East Asia. Journal of Accounting and Economics, 33(3), 401-425. http://dx.doi.org/10.1016/S0165-4101(02)00047-2

Fukuyama, F. (1995). Trust: The social virtues and the creation of prosperity. NY: The free Press.

Gibrat, R. (1931). Les inegalites. Paris: Librairie du Recueil Sirey.

Hausman, J. A. (1978). Specification tests in econometrics. Econometrica, 46(6), 1251-1271. http://dx.doi.org/10.2307/1913827

Kao, L. F., Chen, R. C. Y., \& Li, S. C. (2006). Transparency and deviation between board seat ratio and cash flow rights on firm performance: Evidence from electronic firms in Taiwan. Taiwan Academy of Management Journal, 6(2), 81-104.

Khanna, T., \& Palepu, K. (1997). Why focused strategies may be wrong for emerging markets. Harvard Business Review, 75(4), 41-51.

La Porta, R., Lopez-de-Silanes, F., \& Shleifer, A. (1999). Corporate ownership around the world. Journal of Finance, 54(2), 471-518. http://dx.doi.org/10.1111/0022-1082.00115

La Porta, R., Lopez-de-Silanes, F., Shleifer, A., \& Vishny, R. W. (2002). Investor protection and corporate valuation. Journal of Finance, 57(3), 1147-1170. http://dx.doi.org/10.1111/1540-6261.00457

Lee, C. Y., \& Su, W. C. (2009). R\&D commitment and firm performance: A study of Taiwanese family business. Organization and Management, 2(2), 197-221.

Lee, T. S., \& Yeh, Y. H. (2004). Corporate governance and financial distress: Evidence from Taiwan. Corporate Governance: An International Review, 12(3), 378-388. http://dx.doi.org/10.1111/j.1467-8683.2004.00379.x

Lee, Y. C., \& Ma, T. (2006). The study of the cost of debt financing of Taiwan's family firms. Management Review, 25(3), 69-91.

Liao, Y. H. (2010). Association between board composition, ownership structure and information disclosure level in the annual report. NTU Management Review, 20(2), 209-250. 
Lin, B. R. (2010). Family firm and firm performance: An empirical evidence from Taiwan stock exchange. Soochow Journal of Accounting, 3(1), 53-82.

Lin, Y. F., Hong, C. H., \& Chen, Y. Z. (2011). The relationship between managerial successions of family-controlled non-family-controlled business and relative performances: An empirical study of Taiwan listed companies. Management Review, 30(3), 25-47.

Lins, K. V. (2003). Equity ownership and firm value in emerging markets. Journal of Financial and Quantitative Analysis, 38(1), 159-184. http://dx.doi.org/10.2307/4126768

Masulis, R. W., Wang, C., \& Xie, F. (2012). Globalizing the boardroom: The effects of foreign directors on corporate governance and firm performance. Journal of Accounting and Economics, 53, 527-554. http://dx.doi.org/10.1016/j.jacceco.2011.12.003

Morck, R., Shleifer, A., \& Vishny, R. W. (1988). Management ownership and market valuation: An empirical analysis. Journal of Financial Economics, 20(1-2), 293-315. http://dx.doi.org/10.1016/0304-405X(88)90048-7

Mundlak, Y. (1978). On the pooling of time series and cross section data. Econometrica, 46(1). 69-85. http://dx.doi.org/10.2307/1913646

Oesterle, M. J., Richta, H. N., \& Fisch, J. H. (2013). The influence of ownership structure on internationalization. International Business Review, 22, 187-201. http://dx.doi.org/10.1016/j.ibusrev.2012.03.007

Oxelheim, L., \& Randoy, T. (2005). The Anglo-American financial influence on CEO compensation in non-Anglo-American firms. Journal of International Business Studies, 36, 470-483. http://dx.doi.org/10.1057/palgrave.jibs. 8400144

Portney, L. G., \& Watkins, M. P. (2000). Foundations of clinical research: Applications to practice (2nd ed.). Upper Saddle River, NJ: Prentice Hall.

Pound, J. (1988). Proxy contests and the efficiency of shareholder oversight. Journal of Financial Economics, 20(1-2), 237-265. http://dx.doi.org/10.1016/0304-405X(88)90046-3

Siebels, J. F., \& Knyphausen-Aufseß, D. Z. (2012). A review of theory in family business research: The implications for corporate governance. International Journal of Management Reviews, 14, 280-304. http://dx.doi.org/10.1111/j.1468-2370.2011.00317.x

Singh, A., \& Whittington, G. (1975). The size and growth of firm. The Review of Economic Studies, 42(1), 1526. http://dx.doi.org/10.2307/2296816

Weng, S. Y. (2000). Central agency problem and corporate value on concentrated ownership environment: empirical study of the Taiwan stock market. Working Paper, Catholic University of Fu Jen, New Taipei, Taiwan.

Yang, Y. H., Lin, Y. H., \& Yen, G. F. (2012). A study on efficiency monitoring and interest assimilation in corporate governance: Listed companies in Taiwan. Emerging Markets Finance and Trade, 48(S2), 169 183.

Yeh, Y. H., Lee, T. S., \& Woidtke, T. (2001). Corporate governance and performance: The case of Taiwan. International Review of Finance, 2(1), 21-48. http://dx.doi.org/10.2753/REE1540-496X48S210

Yen, G. F. (1996). A research on cultural-structural relationship of Taiwan family enterprises: The dual-system model and some related managerial problems. Chung Yuan Journal, 24(4), 1-9. http://dx.doi.org/10.1111/1468-2443.00014

Yen, G. F., \& Yang, Y. H. (2012). Efficiency monitoring in the family enterprises dual-system structure: An empirical analysis of Taiwan's financial holding companies. Academy of Taiwan Business Management Review, 8(2), 80-88.

\section{Copyrights}

Copyright for this article is retained by the author(s), with first publication rights granted to the journal.

This is an open-access article distributed under the terms and conditions of the Creative Commons Attribution license (http://creativecommons.org/licenses/by/3.0/). 